\title{
Columnar and radiating aggregates with jarlite from the Ivigtut cryolite deposit, South Greenland
}

\author{
HANS PAULY
}

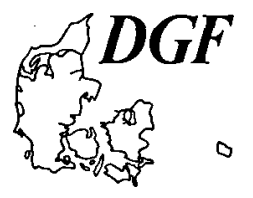

Pauly, H.: Columnar and radiating aggregates with jarlite from the Ivigtut cryolite deposit, South Greenland. Bulletin of the Geological Society of Denmark, vol. 40, pp. 272-279, Copenhagen, 1993-12-30. https://doi.org/10.37570/bgsd-1993-40-12

Most jarlite in the Ivigtut cryolite deposit occurred as $\mathrm{cm}$-sized segregations in fluorite-carrying masses. The conspicuous columnar and radiating aggregates with jarlite occurred only in five places in the quarry. They are composed of mm-wide, $\mathrm{dm}$-long lamellae either in a radiating pattern or in a more or less parallel arrangement.

The major constituent of the lamellae is jarlite in fan-shaped grains $0.2-1 \mathrm{~mm}$ long. They are delineated by seams, a few tenths of a mm wide, of cryptocrystalline topaz and a spherulitic mica which show straight borders towards the jarlite.

The lamellae are prismatic bodies with lozenge shaped cross sections showing angles of $70^{\circ}$ and $110^{\circ}$, the latter often truncated giving $145^{\circ}$.

The faces of the prisms correspond to topaz-coated planes found in the pseudocubic mineral cryolite: pseudo-octahedral and pseudo-dodecahedral planes. The lamellae are regarded as pseudomorphs after prismatic cleavage bodies of cryolite.

The radiating and columnar aggregates formed when $\mathrm{Sr}$-Ba-rich fluids dissolved shattered, topaz-coated cryolite. Simultaneously with the dissolution bøgvadite and strontian barite formed crystals with axes parallel to the crystallographic axes of the former cryolite. The fanshaped/subspherulitic jarlite grains with random orientations formed later, presumably from gel-like masses produced by the total dissolution of the cryolite.

The central parts of the radiating aggregates had bøgvadite crystals in an array lined up after the radial directions, in a matrix of micron-sized scales of strontian barite with a kaolin-like mineral. Tangential bands of the spherulitic mica make the central parts, 5-10 cm across, appear as colloform masses formed from a gel.

Hans Pauly. Technical University of Denmark, bg. 204, Lyngby, DK-2800, Denmark. August 30th, 1991.

\section{Introduction}

Jarlite in columnar aggregates was according to Bøgvad (1933) found in situ at four different places in the cryolite quarry. He described the occurrences as dyke-like formations. His description, when integrated with the map of the quarry at that time, indicates that the dykelike formations were $\mathrm{m}$-long. A further showing of jarlite-bearing aggregates was detected in 1937 in the W wall of the quarry some $20 \mathrm{~m}$ above the floor of the quarry (R. Bøgvad in an unpublished report). It appeared as a $15 \mathrm{~m}$ long, dm-wide selvage around a lensshaped mass of cryolite which in its central part also carried a 2-3 m long accumulation of jarlite-bearing aggregates.

It is estimated that these five occurrences contained around $10 \%$ of the jarlite present in the deposit. The main part of the mineral was recorded as $\mathrm{cm}$-sized inclusions in drill cores from the fluorite-rich masses: the fluorite-cryolite and the fluorite zone (Pauly 1992). The $\mathrm{dm}$-sized samples at hand of the columnar and radiating aggregates came from the five occurrences but no sample can be referred to a specific location.

The designations of these aggregates stem from the peculiar arrangements of the fine-grained minerals constituting them, Fig. 1 and 2. A radiating line pattern is seen in some of the samples. In a few samples it radiates out from a central part where the pattern is accentuated by a number of tangential bands, Fig. 1. Bøgvadite, $\mathrm{Na}_{2} \mathrm{SrBa}_{2} \mathrm{Al}_{4} \mathrm{~F}_{20}$, was detected in this part of such a sample (Pauly and Petersen 1988). In the columnar aggregates the line pattern causes the aggregates to appear as if they were composed of a number of rods or lamellae heaped together in a more or less parallel arrangement, Fig. 2. 


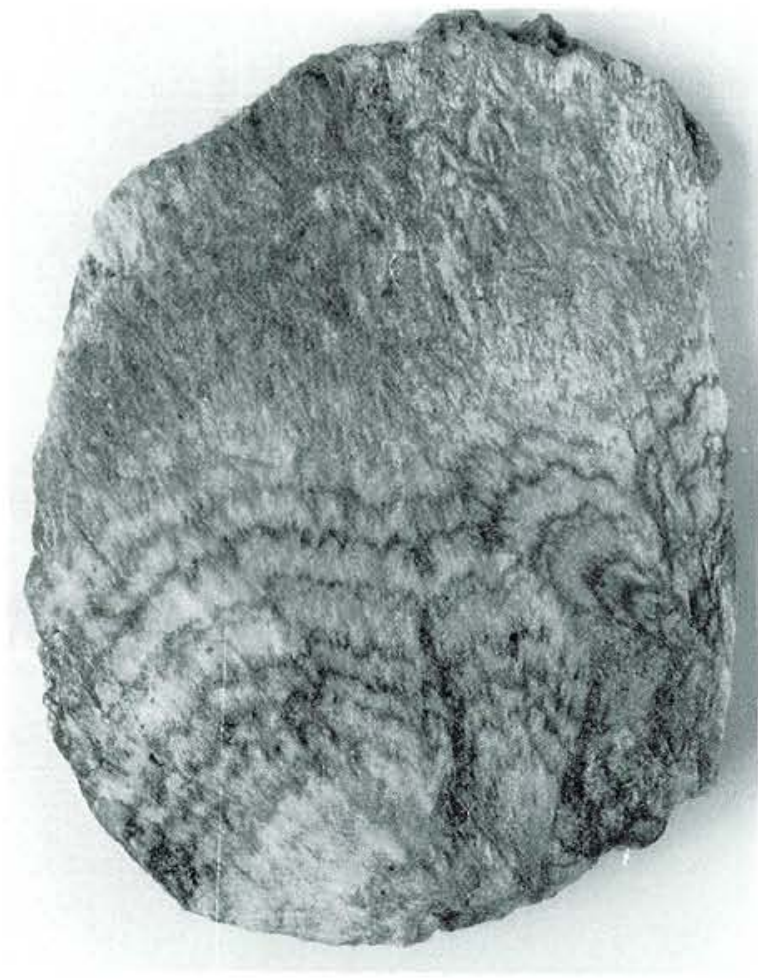

Fig. 1. Radiating aggregate with tangential bands of spherulitic mica in the central part. The uneven surface of the sample masks the radiating pattern. The sample is $9 \times 12 \mathrm{~cm}$.

\section{Geometry of the radiating and the columnar aggregates}

Viewed on sample faces showing the line pattern the aggregates appear to be composed of white to glassy lamellae, $1-5 \mathrm{~mm}$ wide, separated by seams a few tenths of a $\mathrm{mm}$ wide. The seams are often slightly rust coloured, sometimes light greenish or white.

In thin sections, the seams show $\mathrm{cm}$-long, straight borders towards the interior of the lamellae. Sections cut across the lamellae also show the seams with straight borders towards the interior. Here they delineate cross sections of the lamellae with outlines as lozenges or lozenges with truncations of the obtuse angles, Fig. 3. In other words, the aggregates are composed of more or less close lying prismatic bodies. In thin sections perpendicular to the lengths of the prisms the acute angles are found to be around $70^{\circ}$, the obtuse angles around $110^{\circ}$ and the truncations show angles around $145^{\circ}$.

On fracture faces of the aggregates one often observes that the material of the seams has split off from the interior of the prisms along the straight borders leaving plane prism faces exposed. On the broken face of a columnar aggregate, two small protruding prismatic bodies were observed. They were $2 \times 4 \mathrm{~mm}$ in cross section and their exposed lengths were about $3 \mathrm{~mm}$. The angles formed by the six prism faces (not the angles between their face normals) were found to be $70^{\circ}$ and $145^{\circ} \pm 2^{\circ}$.

\section{The central parts of the radiating aggregates}

The central parts fit the overall radiating pattern of the aggregates but differ in appearance and composition. Bøgvadite is a major constituent (Pauly and Petersen 1988). In thin sections it appears in a rather dense array of slightly rectangular crystals 100 to $200 \mu \mathrm{m}$ long. All crystals have the same orientation and their c-axes are parallel to the radial direction of the aggregate. Crystals of ralstonite are frequently found adhering to the bøgvadite crystals. The inter-space contains an extremely fine-grained mass which in the electron microprobe was found to consist of micron sized scales of barite mixed with a kaolin-like mineral (Pauly and Petersen 1988).

Scattered aggregates of slim, fan-shaped grains of jarlite occur between the rows of bøgvadite crystals. The elongated grains of jarlite are roughly parallel to

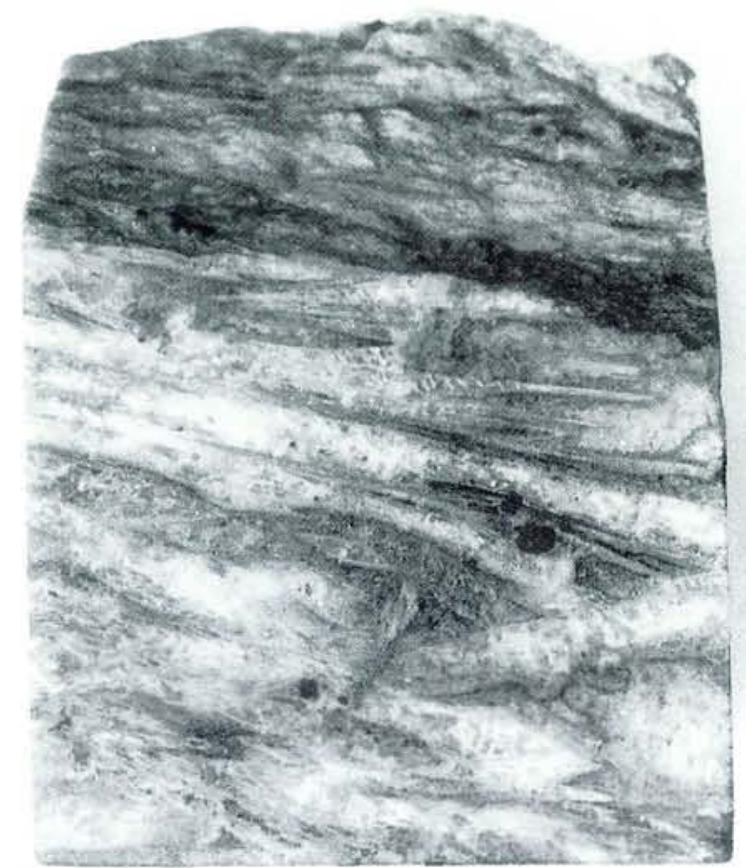

Fig. 2. Cut and polished section through a columnar aggregate. White patches are fine-grained strontian barite in jarlite. Lamellae are cut along their lengths. The area shown is $4 \times 5 \mathrm{~cm}$. 


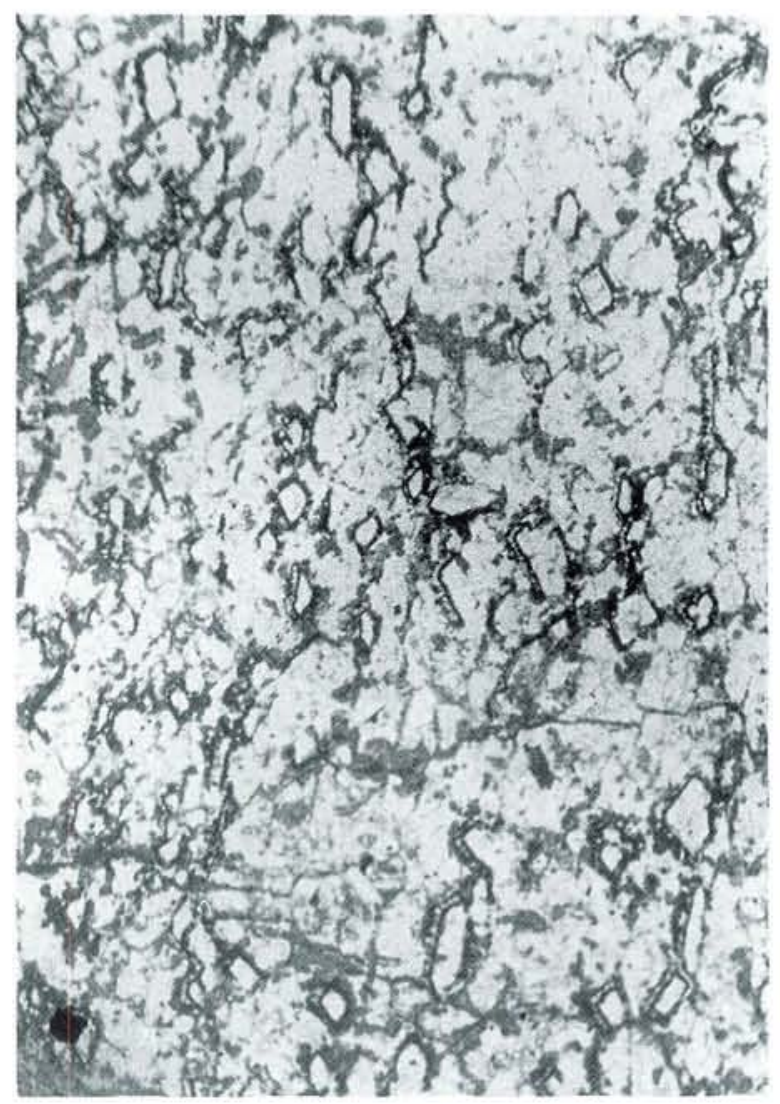

Fig. 3. Thin section, plane light, field is $1 \times 1.5 \mathrm{~cm}$. A number of cross sections through prismatic bodies are seen. The delineating topaz/"ivigtite" appears dark (opaque) because of the fine-grained nature of these silicates. Translucent parts are mainly jarlite.

the rows, i.e. the radial directions of the sample. The tangential bands, Fig. 1, are in thin section seen to consist of clusters of the fine-grained, spherulitic mica "ivigtite" which is a muscovite, variety phengite (Pauly 1992).

\section{The minerals in the radiating and the columnar aggregates}

The minerals constituting the aggregates are described in groups in the following: those forming the seams, those forming the prismatic bodies and those occurring between the prismatic bodies with their seams.

\section{The seams delineating the prismatic bodies}

The spherulitic mica "ivigtite" and the cryptocrystalline, flint-like topaz, in varying proportions, make up the seams. In some samples "ivigtite" may dominate but along the straight border to the interior of the prismatic bodies topaz is usually found. In a number of samples topaz alone forms the seams. The other border of the seams is irregular and bulging and may merge with seams of neighbouring prisms. Sometimes tiny quartz grains or crystals, less than $40 \mu \mathrm{m}$ across, have been observed in the topaz. In samples dominated by "ivigtite" small aggregates of mica flakes, a few hundred um across, have been found. This well crystallized mica is a potassium mica with some $\mathrm{Mg}$ and $\mathrm{Fe}$ and $\mathrm{Si}: \mathrm{Al}>3: 1$, (Pauly 1992)).

Where neighbouring seams merge and form broader areas as seen in thin section, they may enclose small rounded areas of fluorite. From topaz enclosing such areas micron-thin crystals of topaz are seen penetrating the fluorite often as bundles of crystals $20-50 \mu \mathrm{m}$ long.

\section{The prismatic bodies}

Jarlite constitutes the main part of the minerals entirely filling up the interior of the prismatic bodies. It occurs as elongated, curved grains in fan-shaped aggregates crossing the prisms in various directions. Between crossed polars the grains show wavy or brush-like extinction. The fanshaped aggregates sometimes resemble spherulites and true spherulites of jarlite have been observed in a few samples. The columnar aggregates often have slightly curved lath-like and wedge-shaped jarlite grains somewhat coarser than the grains in the radiating aggregates. These jarlite grains are composite having a core usually showing straight borders towards the surrounding mantle-part of the grain; optically the two parts have the same orientation. Electron microprobe analyses (Pauly and Nielsen 1992) showed 1-2\% of $\mathrm{Mg}$ and $\mathrm{K}$ in the mantle parts wereas these elements were nearly absent in the cores.

Within the jarlite there are found grains and aggregates of strontian barite (henceforth barite) and of bøgvadite (a few \% of each). In thin sections cut along the lengths of the prisms, all grains of these two minerals show simultaneous and sharp extinction between crossed polars. The position of extinction is parallel to the directions of the prism in which the grains are situated. In thin sections cut across the prisms, the two minerals show extinctions parallel to the diagonals of the lozenge shapes.

Barite is, in thin sections from some samples, seen to follow the straight outlines of the prisms as elongated 


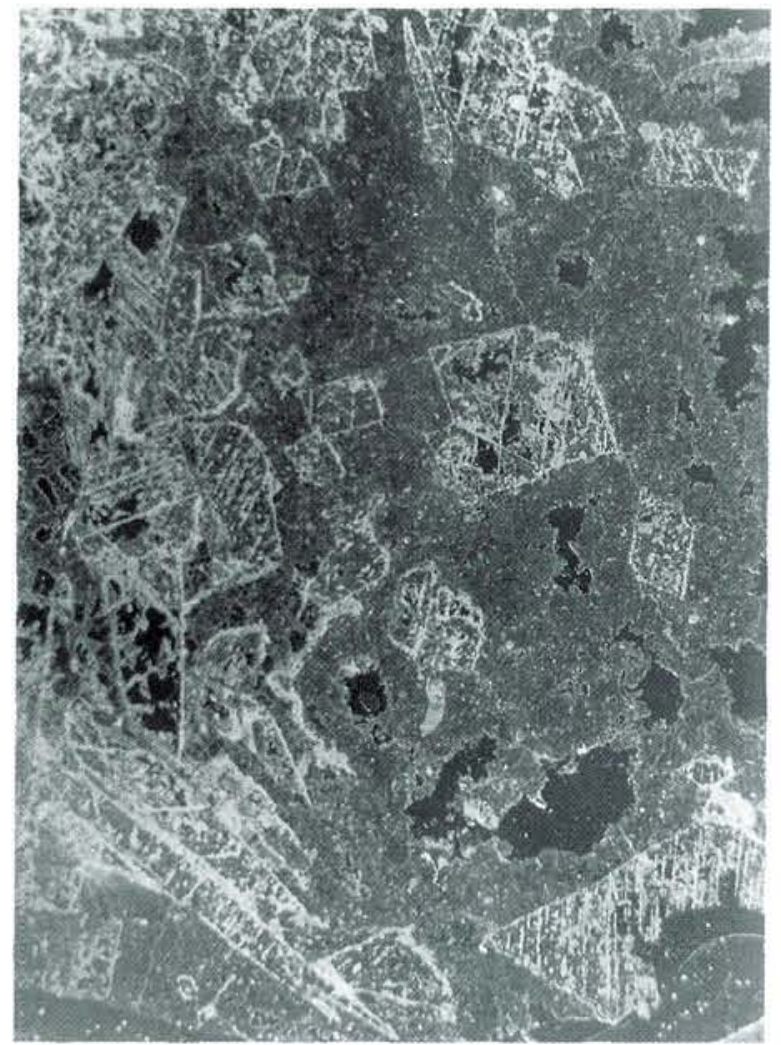

Fig, 4. Thin section, plane light, field is $1 \times 1.5 \mathrm{~cm}$. 1t is photographed against a dark background.

Barite delineates prismatic bodies; ribbons through the cross sections are also barite. Translucent parts are mainly jarlite.

grains or more often as rows of disconnected, small grains. From such grains of barite, thin irregularly shaped protuberances or rows of grains extend into the prisms. In cross sections of the prisms the rows of barite grains are seen to follow the directions of the lines bisecting the obtuse angles. They may appear as a number of ribbons across the prism cross section, Fig. 4.

The single grains of barite, $20-50 \mu \mathrm{m}$ across, often appear as small lozenges in which the line bisecting the acute angle is parallel to the fast direction which, again, is parallel to the line bisecting the obtuse angle of the cross section of the prism in which they are situated.

In columnar aggregates irregularly shaped barite grains up to several mm-long can be seen in thin sections. Large and small barite grains within one prismatic body always show the same optical orientation. This, by the way, explains why it is possible, in suitably inclined light, to see light reflection from single lamellae on broken surfaces of some columnar aggregates. It looks as if a cleavage face was exposed all along the lamella. With a lens however, it is seen that the light is reflected simultaneously from numerous small, white grains scat- tered along the lamella. These grains are the uniformly orientated barite grains seen in thin sections.

In some samples the prismatic bodies have been found delineated only by rows of the small barite crystals. Strings or ribbons of the barite crystals also penetrate the interior of the prisms. Macroscopically the samples appear highly porous like a boxwork. In thin section pores and empty spaces are seen within as well as outside the prisms. Jarlite in spherulite-like aggregates is the main mineral in and outside the prisms. Some fluorite is present between the prisms. Pigment arranged in zones along crystallographic planes indicates grain sizes up to $0.5 \mathrm{~mm}$ for the fluorite. Thin topaz crystals, 10-20 um long, occur in this fluorite and jarlite filling cleavage cracks have also been seen in the fluorite.

Bøgvadite quite often shows crystal outlines and sizes similar to those observed for bøgvadite in the original sample (Pauly and Petersen 1988), i.e. crystals 100-200 $\mu \mathrm{m}$ long. Bøgvadite aggregates may cover areas up to 1 $\mathrm{mm}$ long. Often it is intimately intergrown with barite. Opaque microscopy of the polished thin sections is usually the only mean to distinguish between the two minerals because of the very large difference in refractive indices between the two.

Quartz in small grains, $50 \mu \mathrm{m}$ or less in length, is now and then observed along the straight borderline of the prisms. These quartz grains always show optical orientations differing from grain to grain. Sometimes tiny bipyramidal quartz crystals with short prisms are found in the interior of the prismatic bodies. They are also oriented at random.

\section{Between the prismatic bodies and their seams}

Fluorite, in amounts highly varying from sample to sample, is only found outside the prismatic bodies. It can occur as small, rounded areas enclosed in topaz and it can form elongated, tapering areas $\mathrm{mm}$ to $\mathrm{cm}$ long. Along its border to topaz it is penetrated by thin, 20-50 $\mu \mathrm{m}$ long crystals of topaz distributed in more or less stellate groups. In thin sections it is also seen that this fluorite contains zonally arranged pigment or small cavities. It belongs to the colloform fluorite which consolidated alternating with topaz in the deposit (Pauly 1992). Clear fluorite, that is fluorite which crystallized after the topaz (Pauly 1992), is also present between the prismatic bodies. In this fluorite jarlite can be found as inclusions and filling cleavage fissures. Jarlite can form aggregates of crystals protruding into cavities in this fluorite. In similar surroundings spherulitic thomsenolite is observed in thin sections of some samples. As jarlite likewise may appear as spherulitic aggregates, it is the different refractive indices of the two minerals 
which allow one to distinguish them from each other. Where small cavities are seen in thin sections of these masses, one finds that it is the thomsenolite, not the jarlite, which forms crystals protruding into the cavities.

Crystals of ralstonite may be present in these cavities. Crystals and rounded grain of pyrite, $0.1-2 \mathrm{~mm}$ across, are scattered in the various minerals present. It usually amounts to less than $1 \%$.

Marcasite in crystals about $15 \times 50 \mu \mathrm{m}$ in size was observed in one sample, chalcosite in another and galena, chalcopyrite and sphalerite occasionally occur in the samples.

\section{The origin of the prismatic bodies}

The above general picture of the radiating and the columnar aggregates indicates that they, apart from the central parts, are composed of long, slender prismatic bodies. The minerals constituting them are so finegrained that they can not be responsible for the creation of the prisms. The topaz/"ivigtite" marking the prisms was formed before the other minerals of the aggregates. Of these the $\mathrm{Sr}-\mathrm{Ba}$ minerals were placed within the prisms whereas the $\mathrm{Ca}$ minerals were placed between them. This division is blurred where prisms merge.

The prisms are not only marked by the seams of topaz/"ivigtite" delineating their outer shapes. The strict orientation of all grains of bøgvadite and barite within them clearly reflect an original ordering within the prisms. They obviously represent pseudomorphs of a well crystallized, coarse-grained mineral now totally replaced. This mineral must have been cryolite not only because it is the most likely coarse grained mineral in the deposit but more precisely because of its relations to topaz.

\section{Topaz coating cleavage faces in cryolite and the prismatic bodies}

In the western part of the deposit, coarse grained cryolite has been found transected by mm-thin veins of topaz. On broken surfaces topaz appears as coatings on plane and stepped surfaces up to $40 \mathrm{~cm}$ across (Pauly 1992 from where the following is taken). The stepped surfaces look like parallel aligned prisms. Determinations of the angles between the plane faces showed that the topaz coating correspond to the following crystallographic planes in cryolite: $(101,(10 \overline{1})$ or $(011),(01 \overline{1})$; $(001) ;(100)$ or $(010)$. In the pseudocubic mineral the first four correspond to planes from the pseudo-octa- hedron, then a plane from the pseudo-cube and finally two planes from the pseudo-dodecahedron.

Under normal conditions cryolite shows parting along $\{110\}$ only. The topaz coated, plane fractures are regarded as cleavage planes created in explosion-like events accompanied by precipitation of the cryptocrystalline topaz. "Ivigite", together with topaz, has also been observed coating cryolite (Pauly 1978).

The prismatic bodies constituting the radiating and columnar aggregates display the same set of angles as those found between the mentioned topaz-covered cleavage planes. The prisms with lozenge cross sections showing angles around $70^{\circ}$ and $110^{\circ}$ correspond to prisms composed of faces from the pseudo-octahedron either parallel with the b-axis or the a-axis of cryolite. Prisms showing truncations of the obtuse angles also possess a set of faces from the pseudo-dodecahedron. The pseudo-cube face (001) in the prismatic bodies is marked by the strings or ribbons of barite.

The prominence, in the prismatic bodies, of the pseudo-dodecahedral faces clearly makes them depart from the topaz-coated cleavage planes found in cryolite because these showed the following rank: octahedron, cube and dodecahedron with the latter being quite rare. However this may be, the prismatic bodies are regarded as pseudomorphs after cleavage fragments of cryolite generated in the explosion-like events preceding the topaz precipitation.

Compared to the $\mathrm{cm}$ - to dm-sized stepped surfaces covered by topaz, the prismatic bodies appear small. They may, however, be compared to stepped surfaces on which mm-wide, densely packed steps were seen (Pauly 1992).

The coarse-grained cryolite transected by veins of topaz amounted to more than 100.000 tons whereas the radiating and columnar aggregates hardly represent 200 tons being distributed in the five, m-long, dm-wide, fissures which obviously opened in connection with the explosion-like events.

\section{Sr-Ba-rich fluids in the cryolite deposit}

The violent events mentioned were related to a $\mathrm{Ca}-\mathrm{Al}-$ Si-F-rich residue accumulated in the deeper parts of the deposit during the formation of the siderite-cryolite and the body of pure, white cryolite during Stage 1 in the development of the deposit (Pauly 1992). Increase in gas-pressure in the residue eventually led to the explosive events characterizing Stage 2. Alongside deposition of topaz in repeated explosive events, colloform fluorite consolidated forming the fluorite zone in the deeper parts of the deposit. This mass, about 0.5 million tons, contained nearly $60 \%$ fluorite and $30 \%$ topaz besides weberite, "ivigtite" and some jarlite. Fluorite-cryolite 
formed between this mass and the solid products of Stage 1 through mixing of fragmented cryolite with the products of Stage 2. Cryolite remained stable but chiolite broke down during these processes.

Also present in the residue were $\mathrm{Mg}, \mathrm{K}$ and $\mathrm{Sr}-\mathrm{Ba}$ from which $\mathrm{cm}$-sized segregations of weberite, "ivigtite" and jarlite formed after the colloform fluorite, together with and after late, clear fluorite: These segregations were disseminated through the fluorite zone but fluids rich in $\mathrm{Mg}$ separated from the main fluorite-carrying masses and gave rise to pure weberite accumulations even in the siderite-cryolite bordering the fluorite-cryolite. Similar, specialized fluids rich in $\mathrm{Sr}-\mathrm{Ba}$ collected in the five, m-long, dm-wide fissures giving rise to the radiating and the columnar aggregates. In these processes cryolite was no longer stable.

\section{Replacement of cryolite and development of radiating and columnar aggregates}

The five fissures were situated in rather pure, coarsegrained cryolite transected by topaz veins. A dm-wide, more than $50 \mathrm{~m}$ long vein of topaz was observed in the foot of the W wall in 1937 by $R$. Bøgvad.

Prior to the introduction of the Sr-Ba-rich fluids topaz coatings had formed on shattered cryolite and in cleavage cracks in the cryolite caused by the explosion-like events. After the emplacement of the fluids no largescale disturbances took place.

Cryolite was dissolved by the fluids. The processes started along the borders between cryolite and topaz coatings. Simultancously with the dissolution bøgvadite crystals grew with their crystallographic axes oriented parallel to the axes of the former cryolite, the b-axis of bøgvadite parallel to the c-axis of cryolite. The presence of, or the formation of, $\mathrm{SO}_{4}^{2-}$ ions caused strontian barite to crystallize in tiny crystals along the borders and to penetrate into the prisms following the (001) planes of the cryolite. Each single grain of the replacing barite grew with its crystallographic axes parallel to the axes of the cryolite, the a-axis of barite parallel to the c-axis of the replaced cryolite. The presence of aggregates of the two minerals may indicate that the $\mathrm{SO}_{4}^{2-}$ ions were present in limited amounts during this stage of the processes.

The dissolution processes resulted in a total replacement of the cryolite by jarlite in aggregates where the single grains mostly show random orientation relative to the prismatic bodies.

The differences in chemistry of the core and mantle parts of the composite jarlite grains are regarded as indications of altered conditions during crystallization; a drop in temperature seems likely. Changes in the com- position of the fluids through additions from outside are not indicated in any thin section of the examined samples.

The spherulitic or sub-spherulitic development of jarlite indicates other peculiarities during its crystallization. In this connection it is of interest to consider the variety "meta-jarlite" (Pauly and Nielsen 1992): it consolidated as dense, monomineralic masses of cm-long dendrites. In one part of the deposit it formed $2-3 \mathrm{~cm}$ wide and more than $1 \mathrm{~m}$ long veins or fissure fillings. No reactions were observed in cryolite surrounding these veins. They appear as if they were products of an intruded mass of a paste-like character which on sudden crystallization gave rise to the dendritic mass of jarlite.

The character of the "meta-jarlite" seems to indicate possibilities for the existence of a mobile or fluid phase of "jarlite composition" preceding the consolidated products.

In the prismatic bodies the dissolution of cryolite, which added $\mathrm{Na}$ and $\mathrm{Al}$ to the fluid may initially have lead to the formation of gel- or pastelike masses from which, later on, jarlite formed. Depending on the rate of crystallization spherules, sub-spherulitic and fanshaped grains developed. The relatively coarse grains of jarlite in the columnar aggregates represent a prolonged crystallization of the mass.

Jarlite crystals lining cavities and occurring on crystals of other minerals in cavities undoubtedly formed from solutions of a more common type.

The fluids dissolving the cryolite and giving rise to the minerals in the pseudomorphs of cryolite prisms did not leave signs of their presence within the prisms. Outside, that is between the prisms and in various parts of the samples, particularly in the outer parts of the radiating aggregates, cavities indicate accumulations of the final solutions.

The highly porous aggregates where barite delineates the prismatic bodies clearly indicate accumulations of residual liquids.

\section{Deviating developments}

The macroscopic appearance of the central parts of the radiating aggregates is that of a colloform mass which arose through consolidation of gel-like material.

Crystallization of bøgvadite, $\mathrm{Na}_{2} \mathrm{SrBa}_{2} \mathrm{Al}_{4} \mathrm{~F}_{20}$, followed by ralstonite, $\mathrm{Na}_{\mathrm{x}} \mathrm{Mg}_{\mathrm{x}} \mathrm{Al}_{2-\mathrm{x}}(\mathrm{F}, \mathrm{OH})_{6} \mathrm{H}_{2} \mathrm{O}$ with $\mathrm{x}$ $=0.65$, and subsequent formation of some jarlite in the matrix consisting of the extremely fine-grained barite with "kaolin" seem to indicate introduction of $\mathrm{SO}_{4}^{2-}$ ions late in the sequence.

Attempts at quantitative electron microprobe analyses of the "kaolin" were not successful but one set of analyses may be interpreted as indicating a composition closer to pyrophyllite than kaolinite. The main point is probably that $\mathrm{Al}$ and $\mathrm{Si}$ were present. In some samples 
tiny crystals of quartz substantiate the presence of Si. The tangential bands of spherulitic mica may point to a diffusion of $\mathrm{K}$ into the gel-like material.

Some samples show pseudomorphs after bøgvadite (Pauly and Petersen 1988). It is replaced by strontian barite; $\mathrm{SO}_{4}^{2-}$ ions introduced after the formation of the fluoride obviously caused these extensive alterations. Bøgvadite observed here and there in the radiating and the columnar aggregates often shows mottled appearances between crossed polars. This is believed to signify incipient break-down of the bøgvadite in the surroundings where the sulphate attack lost its impetus.

A peculiar type of sample consists of massive "ivigtite" enclosing triangular and wedge-shaped, white to pink patches in $\mathrm{cm}$-sizes. Thin sections show a pattern of bøgvadite crystals transformed into strontian barite similar to the above mentioned. The triangular patches seem to be fragments of the central parts of radiating aggregates which before or concomitant with the baritepseudomorphism were enclosed in the mass of the spherulitic mica. Somewhat similar pseudomorphed aggregates have been found enclosed in topaz with some fluorite.

Late surges of $\mathrm{SO}_{4}^{2-}$ ions may be responsible for the formation of white, earth-like barite, Sr-free, filling cavities, lined by crystals of jarlite, ralstonite and thomsenolite, in some samples of the radiating aggregates.

Weberite, not normally found in the radiating and the columnar aggregates, has been found in a few samples where it is placed so that the samples seem to represent the meeting of two different parageneses. Weberite being the earlier formed mineral is partly incorporated in the radiating structure together with laths of small albite crystals, an accessory mineral now and then found together with weberite.

In a sample of a columnar aggregate, ralstonite was rather more frequent than usual and weberite grains were observed as nuclei within the ralstonite crystals.

Prosopite veins transecting columnar aggregates clearly show that the latter formed before the appearance of prosopite which belong to Stage 3 in the formation of the deposit (Pauly 1992).

\section{Summary and concluding remarks}

During the formation of the fluorite-bearing masses in the Ivigtut cryolite deposit (around 300.000 tons $\mathrm{CaF}_{2}$ ) $\mathrm{Sr}-\mathrm{Ba}$ accumulated in fluids from which jarlite crystallized as a late mineral within these masses. Sr-Ba occurring as minerals in the deposit amounted to 1.000 tons $\mathrm{Sr}$ (or less) and $\mathrm{Sr}: \mathrm{Ba}$ was around 5:1. In fluorite less than $0.1 \%$ Sr has been found.

A fraction of the $\mathrm{Sr}-\mathrm{Ba}$ fluids (less than $10 \%$ ) escaped from the main masses of fluorite and collected in the five fissures where topaz-coated, shattered cryolite was present. Dissolution of the cryolite eventually led to its replacement by jarlite. The processes started with crystallization of the Ba-rich fluoride bøgvadite and - with addition of $\mathrm{SO}_{4}^{2-}$ ions - strontian barite. The two minerals represent a few per cent of the aggregates. They crystallized simultaneously with the dissolution of the cryolite: their crystallographic axes strictly follow the lattice directions of the replaced mineral. Jarlite formed later apparently from an intermediate gel-like state.

Considerations of the chemical behaviour of the involved divalent elements might help to clarify the complicated relations but is beyond the scope of this presentation.

\section{Acknowledgements}

Electron microprobe determinations for identification of fine-grained phases were made by Lecturer R. Norbach Nielsen and Mrs. Inger Søndergaard, Institute for Metallurgy, Technical University of Denmark and their help is acknowledged. Mr. Ib H. Nielsen is warmly thanked for the carefully prepared polished thin sections. It is a pleasure to thank Dr. J. Bailey for valuable suggestions also improving the English of the manuscript.

\section{Dansk sammendrag}

Bøgvad (1933) fandt mineralet jarlit i nogle usædvanligt udseende prøver, som han betegnede strålede aggregater; på engelsk "columnar aggregates" (søjleformede aggregater). Disse krystallografiske betegnelser er egentlig ikke rigtige da aggregaterne er opbyggede af ganske finkornede mineraler: jarlit forekommer i reglen i korn der er under $1 \mathrm{~mm}$, topas er kryptokrystallinsk, flintagtig og K-glimmeren "ivigtit" er sfarulitisk; de фvrige mineraler findes mest som korn på et par tiendedele mm eller mindre. Makroskopisk fremtræder aggregaterne imidlertid opbygget af mm-brede, cm- til dm-lange lameller: i nogle prøver tæatliggende, strålende ud fra et centralt parti, $i$ andre snarere sammenhobede mere eller mindre parallelt. I det følgende: strålende henholdsvis søjleformede aggregater.

De fandtes (Bøgvad 1933) som m-lange ganglignende dannelser 4 steder $i$ den vestlige del af bruddet. I 1937 fandt $R$. Bøgvad desuden en $15 \mathrm{~m}$ lang, dm-bred aftegning $20 \mathrm{~m}$ oppe $\mathrm{i}$ vestvæggen. Den omkransede et linseformet kryolitparti og viste sig at bestå af jarlitholdige masser. Der var også en jarlitudskillelse i midten af kryolitpartiet. R. Bøgvad kaldte det "jarlit-drusen". Disse jarlitholdige masser skønnes at have indeholdt ca. 200 tons jarlit. Beregninger baseret på de mineralogiske borekærneanalyser viste godt 2000 tons jarlit hovedsageligt som $\mathrm{cm}$-store udskillelser i flusspatholdige materialer.

De central partier $\mathrm{i}$ de strålede aggregater er domineret af bøgvadit krystaller, 0,1-0,2 mm lange. De rektangulære, ens orienterede krystaller ses i tyndsnit som en art brolægning der følger strålernes retning. De ligger i en matrix af $\mu \mathrm{m}$-store skæl af baryt hvori findes et kaolinlignende mineral. Tangentialbånd af "ivigtit" fremhæver strukturen i de centrale partier.

Lamellerne består hovedsageligt af jarlit med et par procent baryt og/eller bøgvadit. De er afgrænset af den mikrokrystallin- 
ske topas og den sfærulitiske "ivigtit". Det mest bemærkelsesværdige er at disse silikater er retlinet begræensede mod lamellernes jarlit etc. I tyndsnit finder man at lamellerne har rhombeformede tværsnit med vinkler på ca. $70^{\circ} \mathrm{og} 110^{\circ}$. Ofte er den stumpe vinkel afstumpet så der fremkommer vinkler på $145^{\circ}$ (alle $\pm 2^{\circ}$ ). Lamellerne er altså prismatiske legemer med 4 eller 6 flader.

Mellem $+\mathrm{N}$ ses alle korn af bøgvadit og baryt at slukke ud parallelt med prismernes langderetning og diagonalerne $i$ deres tværsnit. Alle korn af bøgvadit har den krystallografiske b-akse parallel med halveringslinien til $70^{\circ}$-vinklen, medens baryt har a-aksen parallel med denne linie.

Jarlit forekommer som langstrakte, bøjede korn i vifteformede grupper. De viser ujævn, bølgeagtig udslukning. I nogle prøver ses jarlit som sfæruliter og ofte synes de vifteformede grupper af jarlit at ligne sfæruliter, subsfærulitiske kunne man kalde dem.

I enkelte prøver er prismerne hovedsageligt afgrænset af tynde strenge af barytkorn som også kan danne ribber der i tværsnit af prismerne ses at følge retningen for de stumpe vinklers $\left(110^{\circ}\right)$ halveringslinier.

Flusspat findes kun mellem prismerne, sammen med topas/ "ivigtit". Jarlit findes også her og kan danne krystaller ud i hulrum som netop findes her. Sfærulitisk thomsenolit kan forekomme og kan danne krystaller i hulrum hvor til tider også ralstonit ses. Svovlkis, omkring $1 \%$ eller mindre, findes spredt i aggregaterne. Markasit er fundet i en enkelt prøve. Zinkblende og kobberkis kan forekomme.

Lamellernes prismeform og den strenge orientering af bøgvadit og baryt $\mathrm{i}$ dem viser at prismerne må være pseudomorfoser af et godt krystalliseret, grovkornet mineral. Kryolit er det eneste der kan komme på tale. Prismernes opståen kan forklares ud fra den måde topas optrådte på i kryolitforekomsten. En stor del af den grovkornede, hvide kryolit (omkring 100,000 tons) var gennemsat af mm-tynde topasårer. På brudflader kunne man finde plane eller trappeformede topasbelægninger op til $40 \mathrm{~cm}$ i tværmål. Vinklerne mellem de topasbelagte flader har vist at de svarer til følgende planer i

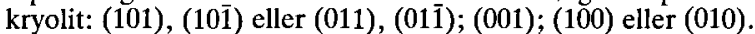
I kryolit, som er pseudokubisk, svarer disse planer til: pseudooktaedret (de 4 første), en pseudoterningflade og flader fra pseudododekaedret. Disse topasbelagte flader anses at svare til spalterevner opstået i kryolit i forbindelse med eksplosionslignende begivender der ledsagede dannelsen af flusspat-kryolit og flusspatzonen. Den mikrokrystallinske, rene topas afsattes i revnerne (helt ned til $50 \mu \mathrm{m}$ brede) fra en luftformig fase der pressedes derind ved eksplosionerne. Vinklerne mellem de nævnte spalteflader i kryolit er de samme som vinklerne i de prismatiske lameller. De anses derfor for at være pseudomorfoser efter prismatiske spaltestykker af kryolit enten langstrakte efter b-aksen eller efter a-aksen. Pseudododekaederfladen (100) eller (010) er hyppig i pseudomorfoserne, medens den i topasbelagte spalterevner i kryolit var mindre hyppig end pseudoterningfladen (001). Denne flade er i pseudomorfoserne markeret af de ovennevnte ribber af barytkorn.

Dannelsen af pseudomorfoserne, d.v.s. replaceringen af kryolit, foregik i de 5 revner og spalter hvor de strålede og de søjleformede aggregater blev fundet. Disse revner dannedes ved de eksplosive begivenheder og $\mathrm{Sr}$-Ba-rige fluide masser trængte ind i dem. De var blevet udskilt fra de restmasser som $i$ den eksplosive fase gav ophav til forekomstens flusspat (mere end 300.000 tons). Restmasserne ophobedes, under stedse stigende tryk, medens hovedparten af forekomsten dannedes (jernspat-kryolit og den rene, hvide kryolit ledsaget af kiolit). Foruden topas og flusspat, der dannedes da de overliggende dele af forekomsten ikke længere kunne modstå trykket, dannedes der efterfølgende weberit, "ivigtit" og jarlit, idet restmasserne også indeholdt $\mathrm{Mg}$ og K.

Samtidig med opløsningen af kryolitprismerne krystalliserede bøgvadit og baryt orienteret efter kryolitens krystalgitter: bøgvadits b-akse parallel med kryolits c-akse medens baryts a-akse blev parallel med denne retning. De andre akser i de to mineraler blev parallelle med a- og b-eller $b$ - og a-akserne $i$ den fortrængte kryolit. Jarlitens mere eller mindre sfærulitiske karakter synes at vise at dette mineral ikke dannedes direkte, men opstod fra en gelagtig substans dannet ved kryolitens fuldstændige opløsning. Ideen om denne totrins-proces understøttes af "meta-jarlits" udformning. Denne variant af jarlit forekommer som dendritiske, monomineralske masser blandt andet som m-lange, $2-3 \mathrm{~cm}$ brede revnefyldninger i jernspatkryolit der grænsede op til flusspat-kryolit. De synes at vare dannet ved injektion af en mobil masse med jarlit-sammensatning, en art pasta eller gel, som ved hurtig krystallisation har givet de dendritiske masser.

Hvad der i ovenstående er omtalt som jarlit dækker egentlig over sammensatte mineralkorn bestående af et kerneparti retlinet begranset mod et omgivende kappeparti. De synes at have forskellige, men ens orienterede krystalgitre; $\mathrm{Mg}$ og K er kun tilstede i kappepartierne; kærnepartierne viser $2 \mathrm{~V}_{\alpha} \leq$ ca. $40^{\circ}$ medens kappepartierne har $2 \mathrm{~V}_{a}$ på godt $80^{\circ}$.

En nærmere forståelse af dannelsen af Sr-Ba-mineralerne kan nok kun fås ved overvejelser af de kemiske forhold for de involverede divalente grundstoffer $\mathrm{i}$ det F-rige miljø hvor sulfationer $\mathrm{i}$ begrænsede mængder åbenbart har været afgørende for blandt andet bøgvadit-dannelsen.

\section{References}

Bøgvad, R. 1933: New Minerals from Ivigtut, Southwest Greenland. Medd. om Grønland 92, no 8, 1-11.

Pauly, H. 1978: Twins in cryolite types from Ivigtut, South Greenland. Bull. Geol. Soc. Denmark, 27 Special Issue, 7-14.

Pauly, H. 1992: Topaz, prosopite and closing stages of formation of Ivigtut cryolite deposit, South Greenland. Meddr Grønland, Geosci. 28, 22 pp.

Pauly, H. and Nielsen, R. Norbach 1992: Jarlite: order-disorder structure suggested by optics, results of new analyses and empirical formulac. Can. Mineral. 30, 449-455.

Pauly, H. and Petersen, O. V. 1988: Bøgvadite, $\mathrm{Na}_{2} \mathrm{SrBa}_{2} \mathrm{Al}_{4}$ $F_{20}$, a new fluoride from the cryolite deposit, Ivigtut, $\mathrm{S}$. Greenland. Bull. Geol. Soc. Denmark, 37, 21-30. 